\title{
ASSESSING POTENTIAL FOR ROOFTOP RAINWATER HARVESTING: AN OPTION FOR SUSTAINABLE RURAL DOMESTIC WATER SUPPLY IN ARID REGION OF HARYANA

\author{
Omvir Singh
} \\ Sushila Turkiya*
}

\begin{abstract}
Water supply to rural communities on a sustainable basis is an important development objective of India. Rainwater harvesting is one of the promising ways of supplementing the surface and underground scarce water resources in areas where existing water supply system is inadequate to meet the demand. The present study is an attempt to find out the rooftop rainwater harvesting potential at micro level. A primary survey of 763 households in an arid Dhani Mohabbatpur village of Hisar district in Haryana was conducted to assess the rooftop rainwater harvesting potential. Potential of rainwater supply from the rooftops of the village residents was estimated using the runoff coefficients for cemented and non-cemented built-up houses including public buildings namely, bus stand, panchayat ghar, child development centre, primary and high schools of the village. The study revealed that the potential of rooftop water harvesting in the village is encouraging and if harvested, it will supplement the water need of village residents. Moreover, it will also reduce the pressure on village public water supply as well as on surface and groundwater resources in the water scarce region.
\end{abstract}

\section{Introduction}

Access to clean and affordable water is one of the fundamental human rights and its round-the-clock supply is essential to life, health and various socio-economic activities. Moreover, it works as a foundation stone for social and economic development of any country in the world. It is used mainly in the domestic, agricultural and industrial sectors. Food production is essentially a function of water availability at farm level. Despite its critical role as a resource, projections by different agencies indicate that due to deteriorating global water supply, an estimated two billion people will lack access to safe drinking water by the middle of $21^{\text {st }}$ century

*Department of Geography, Kurukshetra University, Kurukshetra-136119, India, Email: ovshome@yahoo.com; ovshome@gmail.com. 
(Parmar, 2003). Rising population and urbanisation coupled with climate change may reduce water supply globally during the current century (Murad et al., 2007; Wheida and Verhoeven, 2007). Environmental degradation in many countries of the world is reducing human access to safe potable water. Recent growth in the global economy is having far reaching impact on water resources and their uses. Further, changes in lifestyle and changes in consumption rate of water are also leading to pressure on water resources. Therefore, innovative approaches towards water supply are needed to meet this huge challenge.

Rainwater harvesting is one of the promising ways to meet the water demand in water scarce regions. For many rural households which do not have access to clean drinking water, tapping the rainwater instead of the water pipes, has become a significant way of supplementing access to safe water supply. It is an important technique to confront the increasing shortage of water and to manage the precious water judiciously. Out of the many alternative water sources, rainwater is considered the cheapest source of clean water when available. Apart from providing a source of free water, it requires minimal storage and maintenance cost and brings water at the point of need (Efe, 2006; Opare, 2012). It has become an integral part of societies in remote places where piped water and reliance on wells is not an option (Opare, 2012). Also, it is one of the measures for reducing impact of climate change on water supplies. Rooftop rainwater harvesting has been studied in many parts of the world as a way of easing the burden of lack of access to safe domestic water supply (Goel and Kumar, 2004; J ean-Marc et al., 2007; Aladenola and Adeboye, 2010; Baguma et al., 2010a; Ishaku et al., 2012). Review of literature revealed that rainwater is being used, for example, in hotels in China (Deng, 2003), schools in Taiwan (Cheng, 2003; Cheng and Hong, 2004; Wung et al., 2006), houses and residential buildings in Germany (Herrmann and Schmida, 1999), houses in Australia (Coombes et al., 1999) and in the UK (Fewkes, 1999), amongst others.

In India, the per capita average annual fresh water availability has reduced from 5177 $\mathrm{m}^{3}$ in 1951 to $1820 \mathrm{~m}^{3}$ in 2001 and it is estimated to further come down to $1341 \mathrm{~m}^{3}$ in 2025 and $1140 \mathrm{~m}^{3}$ in 2050 (Kumar et al., 2005). Agarwal (1998) envisages enormous potential of water harvesting in India and emphasises on the importance of rainwater harvesting and its pivotal role in water management. Rainwater harvesting via rooftop and ground catchments is an ancient technique of providing domestic water supply in arid and semi-arid rural areas of India (Agarwal and Narain,1997). It is the best option and preferred as an alternative source of domestic water supply where ground water is inaccessible due to certain technological and environmental problems.State governments in India have been encouraging the people to adopt domestic rooftop water harvesting through subsidised schemes. The water thus collected can meet the immediate domestic requirements. Rainwater harvesting has assumed overriding significance all the more 
in view of depleting ground water levels during the recent droughts in various parts of India (Ariyabandu, 2001). Moreover, water stored from the house rooftop is presumed to be pure and potable. Rainwater harvesting is also a key water supply option that impacted on poverty conditions in Sri Lanka while Brazil also instituted a rainwater harvesting scheme known as 'One Million Rural Cisterns Programme' which resulted in massive improvements in access of households to potable water (UNDP, 2010). Rainwater harvesting has also been a major source of water for communities in Northern Nigeria, Uganda, China, Jordan and other countries in the Middle East over several centuries (Baguma et al., 2010b; Nyong and Kanaroglou, 1999;Zhu et al., 2004).

Water scarcity in arid region of Haryana is a tangible phenomenon and detailed information on rooftop rainwater harvesting potential at the individual household level as a specific case has not been undertaken so far in the State.Therefore, the present research has been carried out as an endeavour to assess the quantitative availability of rainwater harvesting potential on rooftops of individual households in Dhani Mohabbatpur village in arid Hisar district of Haryana to improve our knowledge about the potential of rooftop rainwater harvesting systems at household level.

\section{Environment Setting of the Study Area}

The study village,Dhani Mohabbatpur, is part of Ghaggar-Yamuna alluvial plain and marks agradual transition to the Thar Desert.The aeolian deposits comprising accumulation of sand blown from Thar Desert of Rajasthan are mostly confined in the village.These sand accumulations occupy vast stretches of land and occur in the shape of sandy flats, mounds and ridges at places attaining dunal shapes over the sandy flats. The active and moving sand dune generally occurs in the village. The vegetal cover in the village is scant and it resembles the treeless undulating desert. The village is situated at $29^{\circ} 13^{\prime} \mathrm{N}$ latitude and $75^{\circ} 26^{\prime}$ Elongitude in Adampur tehsil of Hisar district (Figure 1). It sp reads over an area of about $230 \mathrm{ha}$. The village is almost a level plain with medium textured sandy and sandy loam type soils. Soils are poor in organic matter content and nutrients. Wheat and cotton are major crops grown in the village whereas bajra, moong, moth, jowar,mustard, and vegetables are minor crops. Buffaloes, cows, sheep and goats constitute the livestock of the village. Total population of the village is 3803 persons as reported during the field survey and their economy is primarily based on agriculture and livestock. 
Figure 1: Location Map of Dhani Mohabbatpur Village in Hisar District of Haryana.

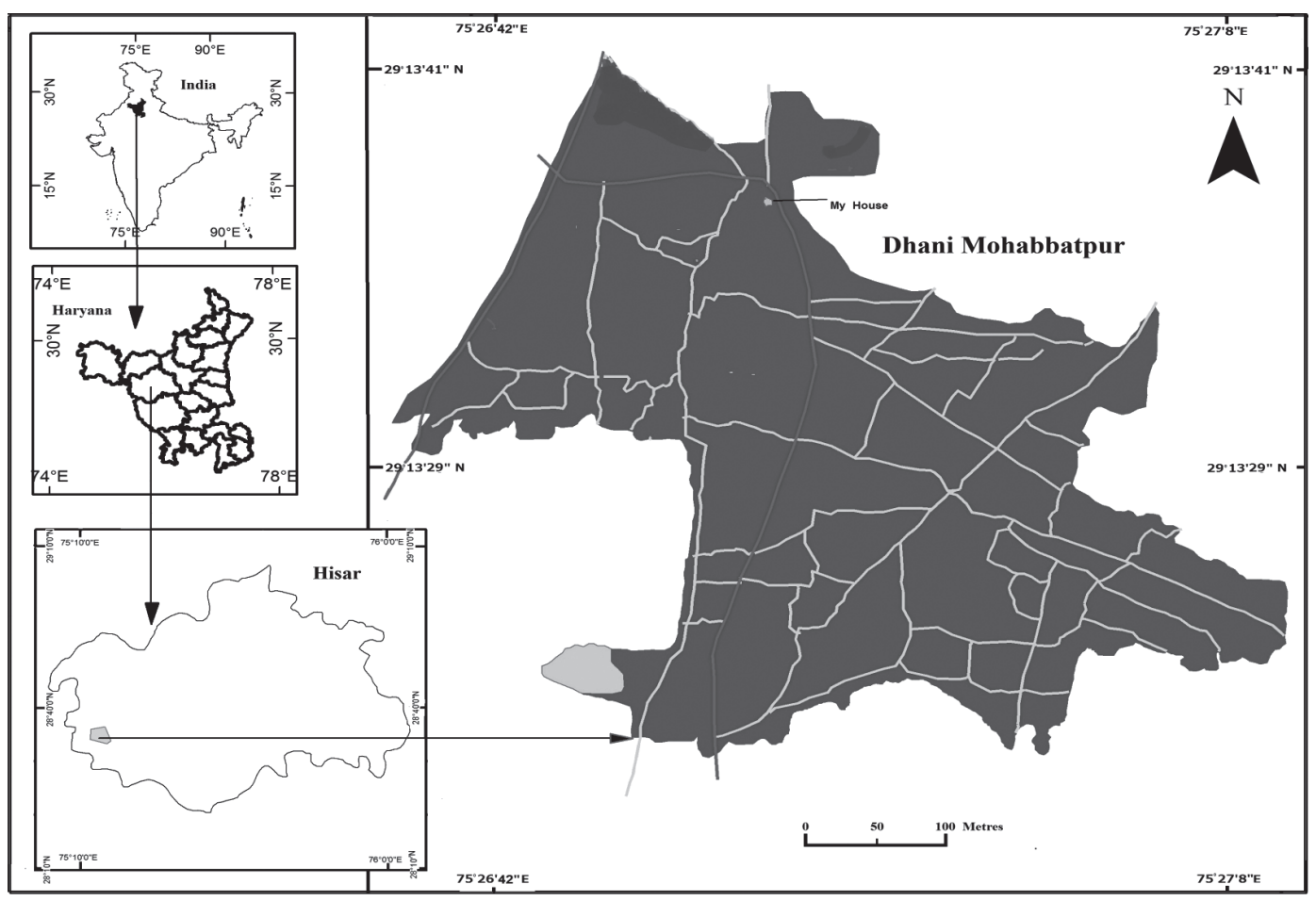

According to Thornthwaite's (1948) classification, the climate of the area can be classified as arid and hot. The study area is mainly characterised by dryness and extremes of temperature except during South-West monsoon period when moist air of oceanic origin penetrates into the region. More than 80 per cent of rainfall is received during this period.Cyclonic rain is also received in the area during winter season (J anuary to February). Mean monthly wind speed in Hisar varies between $2.5-10 \mathrm{~km} / \mathrm{h}$. Dust storms are experienced occasionally during summer months and hail storm during winter months. Fog generally prevails during December and January months. Thunderstorms occur throughout the year but the highest incidences have been observed during monsoon season.
However, the region is regularly traversed by the recurring droughts, famines and scanty and erratic rainfall. The most noticeable famine in the district was recorded in the year 1783 (Bhatia and Kumar, 1987). The district has also experienced noticeable severe droughts and famines during 1860, 1869, 1877, 1896, 1899, 1929,1932,1936,1938-41 and 1987 (Bhatia and Kumar, 1987). The ground water in the village is very deep and it is available at more than 80 $m$ depth from the surface. Moreover, it is saline and unfit for domestic and farm consumption (Singh and Gupta, 2007).

\section{Methodology}

The study is based on both primary and secondary data. A primary survey of 763 individual households of the village was 
conducted from J anuary end to early March 2011. Greater time and effort were employed by the researchers in this survey to ensure data accuracy and reliability.

Measurement of Rooftop Area: The rooftop area of all the 763 individual households and common areassuch as primaryand high schools, bus stand, panchayat ghar and child development centre were measured by taking field measurements using a tape measurer to estimate the rooftop water harvesting potential.

\section{Collection of Rainfall Data and its Variability:}

The study village got its own rain gauge. Therefore, to determine the potential rooftop water supply in the village daily rainfall data from the nearest stations with comparable conditions were collected from Hisar, Hansi and Adampur rain gauge stations for the period 1980-2009. The arithmetic mean method for average amount or volume of rainfall over an area has been ascertained for this study. The amount and number of annual rainy days influences the need and design for rainwater harvesting. If the annual rainy days are less or the dry period is longer, the need for rainwater harvesting in a region is more. To depict the exact degree of variability in rainfall at different stations in Hisar district, its co-efficient of variability was estimated. The runoff coefficients for Dhani Mohabbatpur village were considered as 0.8 for cemented roofs and 0.5 for non-cemented roofs (Khan, 1995).

Calculation of Rooftop Potential Supply: The total amount of water that is received in the form of rainfall over an area is called the rainwater endowment of that area. Out of this, the amount that can be effectively harvested is called the water harvesting potential. It was calculated as (Gould and Nissen, 1999):

$\mathrm{S}=\mathrm{R} \cdot \mathrm{A} \cdot \mathrm{Cr}$

Where, $\mathrm{S}=$ Water harvesting potential

$\mathrm{R}=$ Annual rainfall $(\mathrm{mm})$

$A=$ Area of catchment $\left(\mathrm{m}^{2}\right)$

$\mathrm{Cr}=$ Coefficient of runoff

\section{Results and Discussion}

Rainfall Variability: Unpredictability of rainfall, its duration and temporal as well as spatial distribution create uncertainties in rainwater harvesting. Monthly rainfall variability has occurred in much of India during 1871-2003 (Dash et al., 2007). This precludes an accurate estimation of likely quantities that households could harvest over a specific period. The highest average annual rainfall of $508 \mathrm{~mm}$ was observed in 1988 while the lowest annual rainfall of $83 \mathrm{~mm}$ was observed in 2000 . It was revealed from the analysis that about 261.2 $\mathrm{mm}$ mean annual rainfall is available for rainwater harvesting. July and August are the rainiest months and it is the period when more than 80 per cent of the annual rainfall is received. Knowledge of rainfall variability in Hisar district can help in the choice of suitable size of water harvesting structures. The variability in annual rainfall distributions in the district is more than 40 per cent with high standard deviations. Moreover, high seasonal and annual variations

Journal of Rural Development, Vol. 36, No. 1, January - March : 2017 
and changes in future rainfall distributions are expected with climate change (IPCC, 2007). Variability in rainfall totals and distribution while resulting in uncertainties should not preclude the introduction of rainfall harvesting. Thus, areas with low rainfall totals that are also concentrated within a few months could still institute rainwater harvesting schemes to obtain as much water as they could for their use.

The occurrence of rainy days in Hisar district shows that the intensity of rainfall and number of rainy days are higher during J uneSeptember months. Therefore, these months can be considered potential months for the rooftop rainwater harvesting in the village. Rainfall amount exceeding $25 \mathrm{~mm}$ per hour will generate runoff in huge quantities. Analysis of rainfall demonstrates that the frequency of storms equal to $25 \mathrm{~mm}$ of rainfall accounts for 88 per cent of the total rainy days. Therefore, a good number of rainy days in the district provide a good potential for rooftop water harvesting.

\section{Rooftop Rainwater Harvesting Potential from}

Cemented Houses: The primary survey demonstrated that the village has 763 households. About 97 per cent of the total households in the village have cemented roofs with an area of about $39424.8 \mathrm{~m}^{2}$, which can be used for rainwater harvesting. The cemented ro oftop area of different households in the village varied from $15 \mathrm{~m}^{2}$ to $182 \mathrm{~m}^{2}$. The survey revealed that about 20 per cent of the total cemented households in the village have rooftop area between $40 \mathrm{~m}^{2}$ to $50 \mathrm{~m}^{2}, 19$ per cent between $30 \mathrm{~m}^{2}$ to $40 \mathrm{~m}^{2}, 13$ per cent between $20 \mathrm{~m}^{2}$ to $30 \mathrm{~m}^{2}, 12$ per cent between $50 \mathrm{~m}^{2}$ to $60 \mathrm{~m}^{2}, 9$ per cent between $60 \mathrm{~m}^{2}$ to 70 $\mathrm{m}^{2}, 7$ per cent between $70 \mathrm{~m}^{2}$ to $80 \mathrm{~m}^{2}$ and rest 20 per cent in other categories. However, actual surface area of the rooftops was calculated under each rooftop class to avoid over and under estimation of the potential harvested water on cemented rooftops. Total rooftop area, potential rainwater storage was calculated for each rooftop area class. This analysis demonstrated that about $8238 \mathrm{~m}^{3}$ of water can be harvested on the cemented rooftops of Dhani Mohabatpur village (Table 1). The households having rooftop area between 40 $\mathrm{m}^{2}$ to $50 \mathrm{~m}^{2}$ have the maximum potential followed by $50 \mathrm{~m}^{2}$ to $60 \mathrm{~m}^{2}$. It was also observed during the survey that households with larger number of family members had larger rooftop area. Furthermore, a minimum of 55 litres per capita per day (Ipcd) consumption of water is inevitable for the rural communities in India. This consumption of water includes water for drinking, cooking, bathing and washing of clothes and cleaning of utensils and houses (Anonymous, 2011). Therefore, if rooftop water harvesting is practised in Dhani Mohabbatpur village, the availability of $8238 \mathrm{~m}^{3}$ potential rooftop water can fulfil the domestic water demand of cemented households' population (3672) for 41 days during a year (approximately $1 \frac{1}{2}$ months). 
Table 1: Rooftop Area for the Cemented Houses and Estimation of Potential Rainwater Supply Mean Annual Rainfall: $\mathbf{2 6 1 . 2}$ mm Coefficient of runoff: 0.8

\begin{tabular}{|c|c|c|c|}
\hline $\begin{array}{l}\text { Rooftop } \\
\text { Area }\left(\mathrm{m}^{2}\right)\end{array}$ & $\begin{array}{l}\text { Number of } \\
\text { Households }\end{array}$ & $\begin{array}{l}\text { Total Rooftop } \\
\text { Area }\left(\mathrm{m}^{2}\right)\end{array}$ & $\begin{array}{l}\text { Rooftop Area } \times \text { Mean Annual Rainfall X } \\
\text { coefficient of runoff = Storage of water }(\mathrm{L})\end{array}$ \\
\hline$>150$ & 5 & 797.5 & 166645.6 \\
\hline $140-150$ & 1 & 142.8 & 29839.5 \\
\hline $130-140$ & 2 & 267.5 & 55896.8 \\
\hline $120-130$ & 8 & 970.8 & 202858.4 \\
\hline $110-120$ & 13 & 1514.4 & 316449.0 \\
\hline $100-110$ & 34 & 3484.1 & 728037.5 \\
\hline $90-100$ & 23 & 2175.9 & 454676.1 \\
\hline $80-90$ & 32 & 2707.8 & 565821.9 \\
\hline $70-80$ & 56 & 4188.8 & 875291.6 \\
\hline $60-70$ & 67 & 4389.5 & 917229.9 \\
\hline $50-60$ & 89 & 4848.1 & 1013059.0 \\
\hline $40-50$ & 144 & 6318.3 & 1320272.0 \\
\hline $30-40$ & 142 & 4809.5 & 1004993.1 \\
\hline $20-30$ & 94 & 2367.8 & 494775.4 \\
\hline$<20$ & 27 & 442.1 & 92381.2 \\
\hline Total & 737 & 39424.8 & 8238227.1 \\
\hline
\end{tabular}

Source: Field Survey, 2011.

Rooftop Rainwater Harvesting Potential from Non-Cemented Houses: Out of 763 surveyed households in the village, only 26 households' (3 per cent) rooftop area were found to be constructed with sand and clay (noncemented) material which is locally available. It was observed that most of non-cemented households pertain to lower economic group of the village. The rooftop area of various noncemented households varied from $15 \mathrm{~m}^{2}$ to 56 $\mathrm{m}^{2}$. The total rooftop area under these households was found to be $745 \mathrm{~m}^{2}$ and only
131 persons reside in such houses. The rooftops constructed with sand and clay material generate low runoff coefficients and subsequently low quantities of water. Therefore, rooftop rainwater harvesting potential for these households has been considered very bleak. The analysis revealed that out of the total 26 non-cemented households, 43 per cent households in surveyed Dhani Mohabatpur village have rooftop area less than $20 \mathrm{~m}^{2}, 15$ per cent each between $50 \mathrm{~m}^{2}$ to $60 \mathrm{~m}^{2}, 30 \mathrm{~m}^{2}$ to $40 \mathrm{~m}^{2}$ and 20 
$\mathrm{m}^{2}$ to $30 \mathrm{~m}^{2}$ and 12 per cent between $40 \mathrm{~m}^{2}$ to $50 \mathrm{~m}^{2}$. The calculations of rooftop area, rainfalls and runoff coefficients demonstrated that about $972 \mathrm{~m}^{3}$ of water can be harvested from the noncemented rooftops of the village (Table 2). The non-cemented households having rooftop area between $50 \mathrm{~m}^{2}$ to $60 \mathrm{~m}^{2}$ have the maximum rainwater harvesting potential followed by $>20$ $\mathrm{m}^{2}$ rooftop area households. Therefore, if rooftop water harvesting on non-cemented houses is practised in Dhani Mohabbatpurvillage and $55 \mathrm{Ipcd}$ water is required for domestic chores (drinking, cooking, bathing, washing of utensils, clothes and houses), then the availability of 972 $\mathrm{m}^{3}$ potential rooftop water supply can fulfil the domestic water demand of non-cemented household's population (131) for about 15 days in a year.

Table 2: Rooftop Area for the Non-cemented Houses and Estimation of Potential Rainwater Supply Mean Annual Rainfall: $261.2 \mathrm{~mm}$ Coefficient of runoff: 0.5

\begin{tabular}{cccc}
\hline $\begin{array}{c}\text { Rooftop } \\
\text { Area }\left(\mathrm{m}^{2}\right)\end{array}$ & $\begin{array}{c}\text { Number of } \\
\text { Households }\end{array}$ & $\begin{array}{c}\text { Total Rooftop } \\
\text { Area }\left(\mathrm{m}^{2}\right)\end{array}$ & $\begin{array}{c}\text { Rooftop Area x Mean Annual Rainfall X } \\
\text { coefficient of runoff = Storage of water }(\mathrm{L})\end{array}$ \\
\hline $50-60$ & 4 & 206.5 & 26968.9 \\
$40-50$ & 3 & 130.4 & 17030.2 \\
$30-40$ & 4 & 131.6 & 17187.0 \\
$20-30$ & 4 & 96.8 & 12642.1 \\
$<20$ & 11 & 179.2 & 23403.5 \\
\hline Total & 26 & 744.5 & 97231.7 \\
\hline
\end{tabular}

Source: Field Survey, 2011.

Rooftop Rainwater Harvesting Potential from Primary and High School Buildings: The primary school building of the village has 12 class rooms with one office room. The total rooftop area of the primary school comes around $1004.4 \mathrm{~m}^{2}$. About $210 \mathrm{~m}^{3}$ of water can be harvested through rooftop rainwater harvesting from this building (Table 3). The total strength of students in the school is 389. There are 11 teachers. So there are 400 persons in the school. If 2 lpcd water is allocated to each person in the school for basic requirements (Tapir, 1995), then the daily water requirement in the school will be 800 litres $(400 \times 2)$. Hence, the total potential water available from the primary school building is for 262 days in a year. Therefore, the rooftop rainwater harvesting from the school itself can fulfil the basic water requirement of the school for about $81 / 2$ months during the water scarce period. Moreover, the number of water supply days may increase with reference to student strength, as the total strength of regular students is 70 per cent and further if school holidays during a year are also taken into account then water harvested from the primary school rooftops will be surplus and subsequently it can be utilised for other purposes such as gardening related activities in the school. 
Table 3: Rooftop Area for the Common Buildings and Estimation of Potential Rainwater Supply Mean Annual Rainfall: $\mathbf{2 6 1 . 2} \mathrm{mm}$ coefficient of runoff: $\mathbf{0 . 8}$

\begin{tabular}{lccc}
\hline $\begin{array}{l}\text { Common } \\
\text { Buildings }\end{array}$ & $\begin{array}{c}\text { Total Rooftop } \\
\text { Area in }\left(\mathrm{m}^{2}\right)\end{array}$ & $\begin{array}{c}\text { Rooftop Area x Mean } \\
\text { Annual Rainfall X } \\
\text { coefficient of runoff }= \\
\text { Storage of water }(\mathrm{L})\end{array}$ & Total Stored Water $\left(\mathrm{m}^{3}\right)$ \\
\hline Primary school & 1004.4 & 209879.4 & 210 \\
High school & 1506.6 & 314819.1 & 315 \\
Bus stand & 90.0 & 18806.4 & 19 \\
Panchayat ghar & 81.4 & 17009.3 & 17 \\
Child development centre & 124.9 & 26099.1 & 26 \\
\hline Total & 2807.3 & 586613.4 & 587 \\
\hline
\end{tabular}

Source: Field Survey, 2011.

The high school of the village has 18 rooms including office building and their total rooftop area comes around $1506.6 \mathrm{~m}^{2}$. About $315 \mathrm{~m}^{3}$ of water can be made available to school if rooftop water harvesting is practised from the building. The availability of $315 \mathrm{~m}^{3}$ of potential rooftop water can fulfil the water demand of high school population for 428 days if 2 lpcd water is allocated for their basic requirement in the school. The analysis revealed that high school building has surplus water throughout the year and it can be diverted for domestic use in the village.

Rooftop Rainwater Harvesting Potential from other Public Buildings of Village: Total rooftop area of Dhani Mohabbatpurvillage busstand was measured as $90 \mathrm{~m}^{2}$ and depending on the rainfall and runoff coefficients, the total available water is about $19 \mathrm{~m}^{3}$ (Table 3). Therefore, if rooftop water harvesting is practised in the village bus stand, the availability of $19 \mathrm{~m}^{3}$ potential rooftop water can fulfil the water demand of bus stand visiting population (230 per day) for 41 days during a year if $2 \mathrm{lpcd}$ water per head is allocated to the bus stand users to fulfil their basic requirement. Similarly, the quantity of water available due to potential harvesting from village panchayat ghar and child development centre can fulfil the drinking water demand for 340 and 148 days in a year, respectively. Moreover, it was revealed from the analysis that the available potential rainwater from the rooftops of all common buildings of Dhani Mohabbatpurvillage can make the water available for 273 days in a year for the respective users (approximately 9 months).

Rainwater stored from the rooftops is usually presumed to be free from physical contaminants such as pesticides, lead and arsenic as it does not flow on the ground and 
come into contact with any solid or liquid materials. However, its quality may alter when it passes through the gutters because water comes in contact with dust, debris and leaf litter which is collected on the roof and gutters. Somestudies have indicated that chemical and microbial contamination of rooftop rainwater harvesting systems is common (Magyar et al., 2007; Melidis et al., 2007; Islam et al., 2010). Microbial contamination and other waterquality problems associated with rainwater harvesting systems are most often derived from the catchment area, conveyance system, or storage components. Therefore, regular remediation and maintenance measures such as periodical cleaning of storage tank, discarding water from the first season storm, scrubbing of inner walls and floor, cleaning the cistern using chlorine followed by thorough rinsing and patching of cracks with a non-toxic material and considering access to the cistern while designing the tank, are recommended to enhance and protect the cistern water quality (Salaymeh et al., 2011).Dropping of unhygienic substances by birds on rainwater harvesting catchments can also cause health risks (Pitkanen et al., 2008). Therefore, harvested water needs to be disinfected before use. This can be done either by boiling the water in a vessel before consuming or by dissolving the bleaching powder to the water stored in the tank.

\section{Conclusion}

Rooftop rainwater harvesting systems can provide an alternative to sustainable public water supply systems in arid regions of India. It is likely to reduce the households' dependency to the existing public water supply system characterised by its unreliability. One of the bottlenecks of rooftop rainwater harvesting in the area is seasonality of rainfall and its nonavailability during the dry season and drought periods. Solutions to this include better forecasting from government meteorological agencies. These agencies should periodically provide area-specific information on likely rainfall totals and temporal distribution to enable rural households to strategise on options for rooftop rainwater harvesting. However, lack of funding for storage facilities and almost non-existence of awareness about the technology among masses limit this option. The results obtained from the study are quite encouraging not only for the policy and plan makers but also for the village residents. Rooftop rainwater harvesting will not only solve the water problems in arid areas of Haryana, but it will be highly practicable and meaningful in other parts of the country facing similar situation. The usage of water from rooftop rainwater harvesting structures will ensure sustainability of water and will reduce the vulnerability of water supply for domestic and other uses. 


\section{References}

1 Anonymous (2011), "Report of the Working Group on Rural Domestic Water and Sanitation”, Ministry of Drinking Water and Sanitation, Government of India, New Delhi, pp.19-21.

2 Aladenola, O.O., Adeboye, O.B (2010), "Assessing the Potential for Rainwater Harvesting”, Water Resources Management, 24, pp. 2129-2137.

3 Agarwal, A., Narain, S (1997), “Dying Wisdom: Rise, Fall and Potential of Traditional Water Harvesting Systems in India", Centre for Science and Environment, $4^{\text {th }}$ Citizen's Report, New Delhi.

4 Agarwal, A. (1998), "Rainwater Harvesting in a New Age: When Modern Groundwater and River Exploitation has Reached its Limits",Water Harvesting, SIWI 1998 Paper No. 2, Stockholm, pp. 5- 12.

5 Ariyabandu, R.D.S (2001), "Varieties of Water Harvesting”, in Making Water Everybody's Business: Policy and Practice of Water Harvesting, Centre for Science and Environment, New Delhi.

6 Baguma, D. Loiskandl, W. Darnhofer, I. Jung, H and Hauser, M (2010a), "Knowledge of Measures to Safeguard Harvested Rainwater Quality in Rural Domestic Households",Journal of Water Health, 8, pp. 334-345.

7 Baguma, D. Loiskandl, W. and Jung, H. (2010b), “Water Management, Rainwater Harvesting and Predictive Variables in Rural Households", Water Resources Management, 24, pp. 3333-3348.

8 Bhatia,S.P. Kumar,S (1987), “District Gazetteer of Hisar,'Haryana Gazetteers Organisation, Chandigarh, pp. 1-298.

9 Cheng,C.L.,Hong,Y.T (2004), “Evaluating Water Utilisation in Primary Schools”,Building and Environment, 39, pp. 837-845.

10 Cheng, C.L (2003), “Evaluating Water Conservation Measures for Green Building in Taiwan”, Building and Environment, 38, pp.369-379.

11 Coombes, P.J., Argue, J.R., Kuczera, G (1999), "Fig Tree Place: A Case Study in Water Sensitive Urban Development (WSUD)",Urban Water, 1, pp.335-343.

12 Dash,S.K., enamani, R.K.,Kalsi, S.R.,Panda,S.K (2007), "Some Evidence of Climate Change in Twentieth Century India", Climatic Change, 85, pp. 299-321.

13 Deng, S (2003), “Energy and Water Uses and Their Performance Explanatory Indicators in Hotels in Hong Kong", Energy and Buildings, 35, pp. 775-784.

14 Efe, S.I (2006), “Quality of Rainwater Harvesting for Rural Communities in Delta State, Nigeria”, The Environmentalist, 26, pp.175-181.

15 Fewkes, A (1999), “The Use of Rainwater for WC Flushing: the Field Testing of a Collection System”, Building and Environment, 34, pp. 765-772.

16 Gould, J., Nissen-Peterson, E (1999), "Rainwater Catchment Systems for Domestic Supply: Design, Construction and Implementation", International Technology Publications, London, pp. 27-61.

17 Goel,A.K., Kumar, R (2004), “Economic Analysis of Rainwater Harvesting in a M ountainous Watershed in India", Agricultural Water Management, 71, pp. 257-266.

18 Herrmann, T., Schmida, U (1999), “Rainwater Utilisation in Germany: Efficiency, Dimensioning, Hydraulic and Environmental Aspects, Urban Water, 1, pp. 307-316.

19 IPCC (2007), “Summary for Policymakers: An Assessment of the Intergovernmental Panel for Climate Change", Valencia, Spain.

20 Ishaku, H.T., Majid, M.R., J ohar, F (2012), "Rainwater Harvesting:An Alternative to Safe Water Supply in Nigerian Rural Communities", Water Resources Management, 26, pp. 295-305. 
21 Islam, M.M., Chou, F.N.F., Kabir, M.R., Liaw, C.H. (2010), “Rainwater: A Potential Alternative Source for Scarce Safe Drinking and Arsenic Contaminated Water in Bangladesh", Water Resources Management, 24, pp.3987-4008.

22 Jean-Marc, M.K., Akpofure, E.T., Jeanj, R.B (2007), "Rainwater Harvesting to Improve Water Supply and Sanitation in Rural South Africa", Physics and Chemistry of the Earth, 32, pp. 1050-1057.

23 Khan, M.A (1995), "Traditional Water Management Systems of Western Rajasthan", Congress on Traditional Science and Technology of India, Anna University, Madras, India.

24 Kumar, R., Singh, R.D., Sharma, K.D (2005), “Water Resources of India”, Current Science, 89, pp. 794-811.

25 Magyar, M.I., Mitchell, V.G., Ladson, A.R., and Diaper, C (2007), “An Investigation of Rainwater Tanks Quality and Sediment Dynamics", Water Science and Technology, 56, pp. 21-28.

26 Melidis, P.,A kratos,C.S., Tsihrintzis, V.A., Trikilidou,E (2007),"Characterisation of Rain and Roof Drainage Water Quality in Xanthi, Greece", Environmental Monitoring Assessment, 127, pp. 15-27.

27 Murad, A.A., Al Nuaimi, H., Al Hammadi, M (2007), “Comprehensive Assessment of Water Resources in the United Arab Emirates (UAE)", Water Resources Management, 21, pp. 1449-1460.

28 Nyong, A.O., Kanaroglou, P.S. (1999), “Domestic Water Use in Rural Semi-arid Africa: A Case Study of Katarko Village in Northeastern Nigeria", Human Ecology, 27, pp. 537-555.

29 Opare, S. (2012), "Rainwater Harvesting: An Option for Sustainable Rural Water Supply in Ghana”, Geo Journal, 27, pp. 695-705.

30 Parmar, A. (2003), "Health and Clean Water: Rainwater Retention Helps Green Rajasthan”, Women and Environments, 60-61, pp.14-16.

31 Pitkanen, T., M iettinen, I.T., Nakari, U.M., Takkinen, J ., Neumann, K., Siitonen, A., Kuusi, M., Holopainen, A., and Hänninen, M.L (2008), "Faecal Contamination of a Municipal Drinking Water Distribution System in Association with Campylobacter J ejuni Infections', Journal of Water Health, 6, pp. 365-376.

32 Salaymeh,A.A., Khatib,I.A.A., and Arafat,H.A (2011), “Towards SustainableWater Quality:Management of Rainwater Harvesting Cisterns in Southern Palestine," Water Resources Management, 25, pp. 17211736.

33 Singh, S., Gupta, S (2007), “Groundwater Information Booklet Hisar District, Haryana,"Central Ground Water Board, North-western Region, Government of India, Chandigarh.

34 Tapir, N (1995), "Improved Ro of Rainwater Harvesting in Primary Schools", Paper Presented at the $7^{\text {th }}$ International Rainwater Catchment Systems Conference, Beijing.

35 Thronthwaite, C.W (1948), "An Approach towards a Rational Classification of Climate,' Geographical Review, 38, pp. 55-94.

36 UNDP (2010), "What Will It Take to Achieve the Millennium Development Goals?,'An International Assessment, New York: United Nations.

37 Wheida, E., Verhoeven, R (2007), "An Alternative Solution of the Water Shortage Problem in Libya”, Water Resources Management, 21, pp. 961-982.

38 Wung, T.C., Lin, S. H., Huang, S. M (2006), "Rainwater Reuse Supply and Demand Response in Urban Elementary School of Different Districts in Taipei",Resource Conservation and Recycling, 46, pp.149167.

39 Zhu, K., Zhang, L., Hart, W., Liu, M., Chen, H (2004), “Quality Issues in Harvested Rainwater in Arid and Semi-arid Loess Plateau of Northern China", Journal of Arid Environments, 57, pp. 487-505. 